\title{
TRAINING OF TRAINER PENANGANAN ANAK DENGAN GANGGUAN SPEKTRUM AUTISME BAGI GURU SEKOLAH LUAR BIASA DAN GURU PEMBIMBING KHUSUS SEKOLAH INKLUSI SE-JAWA TIMUR
}

\author{
TRAINING OF TRAINERS MANAGEMENT OF CHILDREN WITH Autism SPECTRUM DISORDERS FOR \\ SPECIAL SCHOOL TEACHERS AND SPECIAL GUIDANCE TEACHER FOR INCLUSIVE SCHOOLS \\ THROUGHOUT EAST JAVA
}

\author{
Dinari Sariwati \\ Fakultas Psikologi Universitas Airlangga \\ E-mail: dinarisariwati@gmail.com
}

Muryantinah M. Handayani

Fakultas Psikologi Universitas Airlangga

E-mail: muryantinah.mulyo@psikologi.unair.ac.id

\begin{abstract}
ABSTRAK
Penelitian ini bertujuan untuk mengetahui efektifitas training of trainer penanganan anak dengan gangguan spektrum Autisme bagi guru SLB dan GPK sekolah inklusi se-Jawa Timur. Training of Trainer Penanganan Anak dengan Autisme ini memberikan informasi terbaru berkaitan dengan karakteristik gejala Autisme secara komprehensif, serta membekali peserta dengan strategi penanganan anak dengan Autisme dengan menggunakan pendekatan TEACCH yang telah terbukti secara empiris (evidence based) dapat mendukung berkembangnya perilaku fungsional pada anak dengan Autisme. Pelatihan yang diarahkan pada pengembangan pengetahuan dan keterampilan peserta dalam penanganan Autisme ini dilaksanakan dengan metode ceramah, role play, simulasi dan praktik pembuatan planning matrix, alat bermain dan independence work system. Subjek penelitian berjumlah 73 orang yang terdiri dari guru SLB dan GPK sekolah inklusi yang mewakili 38 kota/kabupaten, yang diseleksi dari 114 peserta Bimbingan Teknik Pengembangan Kemampuan Komunikasi pada Anak dengan Autisme se-Jawa Timur pada akhir tahun 2017. Pelatihan ini dilaksanakan pada tanggal 25-29 September 2018 di Hotel Pelangi, Malang. Hasil dari pengolahan data menunjukkan adanya peningkatan pengetahuan dan keterampilan peserta setelah mengikuti pelatihan. Berdasarkan uji statistik pada evaluasi pembelajaran pengetahuan diketahui nilai $\mathrm{t}=-13,137$ dan nilai $\operatorname{Sig}=0,000(\mathrm{p}<0,005)$ yang dapat diartikan bahwa terdapat perbedaan yang signifikan antara pengetahuan peserta sebelum dan setelah diberikan pelatihan. Pada level evaluasi perilaku terdapat peningkatan keterampilan peserta dalam membuat planning matrix, alat bermain dan individual work system.
\end{abstract}

Kata kunci: pelatihan penanganan anak dengan gangguan spektrum autism, role play, mentoring

\begin{abstract}
This study aims to determine the effectiveness of training of trainers management of children with autism spectrum disorders for special school teachers and special guidance teacher for inclusive schools throughout East Java. This Training of Trainers Management of Children with Autism provides the latest information relating to the characteristics of autism symptoms comprehensively, and equips participants with strategies for managing children with autism using the TEACCH approach that has been proven empirically (evidence based) to support the development of functional behavior in children with autism. The training aimed at developing the knowledge and skills of participants in handling autism was carried out using the lecture, role play, simulation and planning matrix making practices, playing tools and independence work system. There were 73 research subjects consisting of SLB teachers and inclusive school GPK representing 38 cities / regencies, selected from 114 participants of the Communication Skills Development Skills Training for Children with Autism throughout East Java at the end of 2017. This training was held on the 25-29 September 2018 at Pelangi Hotel, Malang. The results of data processing indicate an increase in participants' knowledge and skills after attending the training. Based on statistical tests on the evaluation of knowledge learning is known the value of $t=-13.137$ and the value of Sig $=0.000(p<0.005)$ which can mean that there are significant differences between participants' knowledge before and after being given training. At the
\end{abstract}


behavioral evaluation level there is an increase in participants'skills in making planning matrix, playing tools and individual work systems.

Keywords: training in managing children with autism spectrum disorders, role play, mentoring.

\section{PENDAHULUAN}

Istilah "autism" pertama kali digunakan pada tahun 1908 oleh Eugen Bleuler untuk pasien skizofrenia yang menunjukkan gejala menarik diri yang parah. Kemudian pada tahun 1943, Leo Kanner, seorang psikiater anak dari Amerika melakukan penelitian terhadap 11 anak. Anak-anak ini memiliki gejala kesulitan dalam interaksi sosial, hambatan dalam beradaptasi dengan perubahan, daya ingat yang baik, sensitive terhadap stimulus (terutama suara), resisten dan alergi terhadap makanan tertentu, memiliki potensi kecerdasan yang baik, ekolalia atau mengulang perkataan orang lain dan kesulitan untuk melakukan kegiatan secara spontan. Secara terpisah, pada tahun 1944 Hans Asperger melakukan penelitian terhadap sekelompok anak-anak. Anak-anak ini juga menunjukkan gejala yang serupa dengan temuan Kanner. Akan tetapi anak-anak dalam penelitiannya tersebut tidak menunjukkan ekolalia sebagai masalah bahasa. Ia juga menemukan bahwa sebagian besar anak-anak terlihat kikuk dan memiliki hambatan keterampilan motorik halus.

Penelitian berikutnya dilakukan oleh Bruno Bettelheim, yang meneliti pengaruh 3 sesi terapi pada anak-anak yang menunjukkan gejala Autisme. Ia menyatakan masalah yang dihadapi anak-anak ini disebabkan oleh ibu yang dingin. Kanner and Bettelheim juga membuat hipotesis bahwa anak dengan Autisme memiliki ibu yang dingin. Bernard Rimland, seorang psikolog dan orangtua dari anak dengan autism, tidak setuju jika anak dengan Autisme disebabkan oleh pengasuhan yang bermasalah. Pada tahun 1964, Bernard Rimland memublikasikan artikel dengan judul: Infantile Autism: The Syndrome and its Implications for a Neural Theory of Behavior. Pada tahun 1980an penelitian dalam Autisme mencapai momentum, dimana diyakini bahwa pengasuhan bukan penyebab Autisme dan ditemukan autism disebabkan gangguan neurologis dan genetik.

Seiring dengan perkembangan penelitian dan pengetahuan mengenai Autisme, pemahaman tentang karakteristik Autisme dan penanganan yang tepat semakin berkembang ke arah positif. Panduan diagnosa Diagnostic and Statistical Manual of Mental Disorder (DSM-5) menjelaskan bahwa individu dengan gangguan spektrum Autisme cenderung memiliki kesulitan dalam berkomunikasi, seperti kesulitan dalam merespons percakapan dengan tepat, memahami interaksi nonverbal atau membangun pertemanan. Individu dengan gangguan spektrum Autisme seringkali juga sangat bergantung pada rutinitas, sangat peka pada perubahan atau sangat terfokus pada benda tertentu. Gangguan ini disebut gangguan spektrum karena variasi kemunculan gejalanya cukup besar, ada individu yang menunjukkan gejala ringan dan ada pula yang jauh lebih parah (American Psychiatric Association, 2013). Manifestasi Autisme juga sangat beragam antar individu dan dalam diri individu dari waktu ke waktu (National Research Council, 2001).

Berbagai penelitian menunjukkan adanya peningkatan jumlah individu dengan autism di berbagai negara. Salah satunya adalah laporan penelitian berjudul "The Prevalence of Autism in Australia: Can it be established from existing data?" yang diterbitkan oleh Autism Advisory Board on Autism Spectrum Disorders pada tahun 2007. Laporan ini menunjukkan bahwa berdasarkan data dari seluruh negara bagian dan wilayah Australia, diperkirakan prevalensi individu dengan gangguan spektrum Autisme berjumlah 62,5 per 10.000 anak usia 6 hingga 12 tahun. Dengan kata lain, rata-rata ada satu dari 160 anak pada rentang usia tersebut yang mengalami gangguan spektrum Autisme, atau 1:160. Laporan ini juga menyebutkan bahwa angka serupa juga ditemukan di Amerika Serikat, sebagaimana diumumkan oleh Centre for Disease Control and Prevention, bahwa prevalensi anak dengan gangguan spektrum Autisme adalah $1: 150$ (66,5 per 10.000).

Meskipun belum ada data resmi di Indonesia, diperkirakan jumlah individu dengan autism saat ini cukup banyak. Feinstein (2010) menyatakan bahwa meskipun awalnya Autisme dipandang sebagai kondisi yang lebih banyak dialami oleh masyarakat Barat, hanya muncul di negara-negara berteknologi tinggi yang didominasi oleh struktur keluarga inti, serta banyak dialami oleh keluarga dari kalangan sosial ekonomi menengah ke atas, saat ini Autisme dipandang tidak memiliki batas geografis ataupun sosial. Tingkat prevalensinya pun hampir identik pada sebagian besar negara di dunia, kecuali beberapa bagian spesifik.

Sebagaimana dimuat pada situs Republika Online tertanggal 9 April 2013 (Hazliansyah,2013), Diah Setia, Direktur Bina Kesehatan Jiwa Kementerian Kesehatan, pada seminar "Diagnosis Akurat, Pendidikan Tepat dan Dukungan Kuat untuk Menciptakan Masa Depan Anak Autisme yang Lebih Baik" di Jakarta menyampaikan bahwa "Bila diasumsikan dengan prevalensi Autisme 1,68 per 1000 untuk anak di bawah 15 tahun, dimana jumlah anak usia 5-19 tahun di Indonesia mencapai 66.000.805 jiwa berdasarkan data BPS tahun 2010, maka diperkirakan terdapat lebih dari 112.000 anak penyandang Autisme pada rentang usia 5-19 tahun."

Peningkatan jumlah individu dengan Autisme ini, termasuk di Indonesia, tentunya membutuhkan respons yang sesuai. Sebagaimana diungkapkan oleh Autism Association of Western Australia, salah satu penyedia layanan komprehensif 
bagi individu dengan Autisme di Australia, berbagai penelitian menunjukkan bahwa, meskipun penyebab Autisme masih belum diketahui secara pasti, berbagai program telah terbukti dapat mengurangi berbagai kesulitan yang dialami oleh individu dengan Autisme dan meningkatkan kualitas hidup keluarga mereka. Dengan pengajaran yang tepat, anak dengan autism dapat diajari untuk berkomunikasi menggunakan sistem komunikasi verbal atau visual dan juga dapat didampingi untuk menghadapi perubahan dan mengembangkan berbagai keterampilan sosial yang dibutuhkan dalam kehidupan sehari-hari.

Menghadapi situasi ini, maka perlu diselenggarakan program Pelatihan Penanganan Anak dengan Gangguan Spektrum Autisme bagi para guru dari sekolah khusus ataupun sekolah inklusi yang dikelola oleh pemerintah di Jawa Timur. Pemilihan sasaran program ini dilandasi oleh urgensi untuk mengembangkan kemampuan dan keterampilan guru yang bekerja di sekolah luar biasa atau sekolah inklusi sehingga mereka dapat menfasilitasi perkembangan siswanya yang mengalami Autisme dengan optimal.

Target dari program Pelatihan Penanganan Anak dengan Gangguan Spektrum Autisme ini berupa peningkatan pengetahuan dan keterampilan peserta program untuk memahami dan menangani anak dengan autism Secara spesifik, setelah mengikuti program ini, peserta akan mampu: menjelaskan definisi dan karakteristik Autisme, menyusun matriks untuk mengidentifikasi karakteristik, dampak dan strategi penanganan Autisme pada ranah komunikasi, bermain, sosial, pemrosesan informasi, pemrosesan sensori, motorik dan perilaku serta mendemonstrasikan strategi-strategi dasar untuk menangani anak dengan Autisme.

\section{METODE}

Pelaksanaan kegiatan Pelatihan Penanganan Anak dengan Gangguan Spektrum Autisme dilakukan selama 5 hari, dengan desain pelatihan yang mencakup:

1. Ceramah, diskusi dan tanya jawab untuk mengembangkan pemahaman peserta akan materi

2. pelatihan. Materi yang diberikan meliputi: Pengantar dan overview materi, apakah autism, Penggunaan matriks untuk autism, Karakteristik, implikasi dan strategi komunikasi, Karakteristik, implikasi dan strategi bermain, Karakteristik, implikasi dan strategi sosial, Karakteristik, implikasi dan strategi pemrosesan informasi, Karakteristik, implikasi dan strategi pemrosesan sensori, Karakteristik, implikasi dan strategi keterampilan motorik kasar dan halus, Karakteristik, implikasi dan strategi perilaku.
3. Role play dan penggunaan multimedia (video) untuk mengasah keterampilan dasar peserta dalam mengidentifikasi karakteristik Autisme dan mengaplikasikan strategi penanganannya.

4. Praktik melakukan observasi untuk mengidentifikasi karakteristik autism dan mendesain strategi penanganan yang sesuai yang dituangkan dalam pengisian planning matriks. Selain praktik menyusun planning matriks, peserta juga praktik merancang alat bermain dan independence work system yang sesuai dengan kasus yang disajikan.

5. Mentoring dilakukan dalam kelompok-kelompok kecil, yang masing-masingnya didampingi oleh satu mentor yang merupakan dosen Fakultas Psikologi Unair. Mentoring dilakukan untuk mendampingi peserta dalam memahami dan menguasai materi yang diberikan dalam sesi ceramah serta membimbing peserta untuk melakukan praktik di kelas. Setelah peserta melakukan praktik, mentor juga akan mendampingi peserta untuk mengevaluasi hasil praktik mereka dan memberikan umpan balik untuk melakukan perbaikan yang sesuai.

Subjek penelitian berjumlah 73 orang yang terdiri dari guru SLB dan GPK sekolah inklusi se-Provinsi Jawa Timur, dimana pengambilan Subjek menggunakan teknik purposive sampling. Subjek dipilih berdasarkan penilaian hasil belajar peserta pada saat menjadi peserta Bimbingan Teknik Layanan Autisme 2017.

\section{HASIL DAN PEMBAHASAN}

Kirkpatrick (2007) menjelaskan bahwa evaluasi terhadap efektivitas pelatihan mencakup 4 level, yaitu evaluasi reaksi, evaluasi pembelajaran, evaluasi perilaku dan evaluasi hasil. Evaluasi reaksi digunakan untuk mengukur kepuasan peserta pelatihan terhadap materi, fasilitas, strategi penyampaian materi serta media pembelajaran yang tersedia. Berdasarkan hasil reaction sheet, peserta merasa puas terhadap pelatihan yang diberikan dimana $26,92 \%$ memberikan penilaian sangat baik, $67,31 \%$ menilai baik dan 5,77\% menilai cukup.

Evaluasi pembelajaran diperoleh dari hasil pretest dan post test Berdasarkan hasil analisis diketahui bahwa $t=-13,137$ dan nilai $\operatorname{Sig}=0,000(p<0,005)$ maka terdapat perbedaan yang signifikan antara pengetahuan peserta sebelum dan setelah diberikan pelatihan. Pengetahuan peserta sesudah pelatihan lebih tinggi dibandingkan dengan pengetahuan peserta sebelum pelatihan (mean setelah pelatihan $=54.9863$ $>$ mean sebelum pelatihan $=36.6027$ ).

Evaluasi perilaku dinilai secara kualitatif terhadap keterampilan peserta dalam membuat planning matrix, alat bermain dan individual work system berdasarkan kasus 
yang dihadapi. Peserta dapat membuat planning matrix secara detail dengan mengobservasi karakteristik anak dengan Autisme, kemudian melakukan analisa terhadap dampak yang akan dihadapi anak berdasarkan karakteristiknya serta menyusun sebuah strategi untuk mengatasi dampak tersebut. Peserta pelatihan dapat menentukan 2 dampak yang paling besar untuk dibuat strategi yang rinci untuk mengatasi dampak tersebut. Peserta dapat membuat alat bermain dengan barang-barang yang ada di sekitarnya sebagai sarana untuk mengembangkan kemampuan bermain anak dengan Autisme. Peserta juga dapat membuat rancangan individual work system sesuai dengan karakteristik anak dalam planning matrix untuk mengembangkan kemandirian anak dengan autism dalam melakukan serangkaian aktivitas belajar.

Menurut Mondy (2008) pelatihan merupakan serangkaian aktivitas yang dirancang guna memberi pengetahuan dan keterampilan yang dibutuhkan para pembelajar untuk dapat melaksanakan pekerjaan mereka pada saat ini. Pelatihan penanganan anak dengan autism ini terbukti efektif dalam meningkatkan pengetahuan dan keterampilan para guru dan terapis untuk dapat mengidentifikasi karakteristik anak dengan autism, menganalisa dampak yang mungkin terjadi dan menyusun dan mempraktikkan strategi untuk membantu mengembangkan anak dengan autism sesuai dengan karakteristik masing-masing. Johnson (2001) menyatakan bahwa efektivitas suatu pelatihan ditentukan oleh beberapa faktor, yaitu partisipasi, iklim pelatihan, gaya belajar partisipan, strategi dan teknik pelatihan, topik pelatihan, dan fasilitas pendukung. Dalam pelatihan ini, faktor-faktor yang mempengaruhi keberhasilan pelatihan adalah:

1. Partisipasi. Peserta pelatihan berpartisipasi aktif selama mengikuti pelatihan. Mereka aktif bertanya dan melaksanakan penugasan yang diberikan.

2. Iklim pelatihan. Pelatihan dilaksanakan selama 5 hari berturut-turut di hotel yang nyaman sehingga peserta dapat menyerap materi dengan lebih baik.

3. Fasilitas pendukung. Fasilitas pendukung pelatihan meliputi handout materi, ruangan, konsumsi, alat peraga dan blind case membuat peserta bisa langsung mempraktikkan materi yang disampaikan oleh pemateri.

4. Strategi dan teknik pelatihan. Penggunaan metode ceramah, diskusi, role play dan mentoring mendukung keberhasilan pelatihan dengan memberikan pengetahuan dan keterampilan secara langsung kepada peserta.

\section{SIMPULAN DAN SARAN}

\section{Simpulan}

Berdasarkan hasil pelatihan penanganan anak dengan autism bagi guru SLB dan GPK sekolah inklusi se Jawa Timur dapat disimpulkan bahwa terjadi peningkatan pengetahuan dan keterampilan para guru dalam mengidentifikasi karakteristik anak dengan autism, menganalisa dampak yang ditimbulkan serta menyusun strategi yang harus dilakukan untuk mengatasi dampak yang terjadi sampai dengan membuat alat bermain serta individual work system sesuai karakteristik anak dengan autism.

\section{Saran}

Berdasarkan hasil temuan selama pelatihan, dapat dikemukakan beberapa saran sebagai

1. Bagi peserta pelatihan

Disarankan kepada peserta pelatihan dapat terus mengembangkan pengetahuan dan keterampilan dengan mempraktikkan di tempat bekerja dan membagi pengetahuan dan keterampilannya kepada teman sejawat dimana mereka bekerja.

2. Bagi kepentingan penelitian dan pengabdian masyarakat di masa mendatang

Disarankan untuk melakukan pelatihan lanjutan yang lebih spesifik sesuai dengan kebutuhan peserta pelatihan di setiap jenjang pendidikan.

3. Bagi pemerintah daerah dan pengambil kebijakan Kompetensi SDM yang memberikan layanan langsung pada siswa dengan autism perlu terus ditingkatkan pengetahuan dan keterampilannya dalam memberikan layanan pendidikan untuk anak dengan autism. Salah satu cara meningkatkan kompetensi SDM adalah melalui pelatihan yang berkesinambungan

4. Bagi perguruan tinggi

Perguruan tinggi sebagai lembaga pendidikan yang terus menerus melakukan kajian dan penelitian mengenai penanganan anak dengan autism sangat diperlukan untuk mengambil peran secara berkelanjutan dalam melakukan pendampingan kepada sekolah-sekolah, pusat terapi maupun instansi lainnya yang memberikan layanan kepada anak dengan gangguan spectrum autism.

\section{DAFTAR PUSTAKA}

American Psychiatric Association. 2013. DSM-5 Autism Spectrum Disorder Fact Sheet. Diakses pada 30 April 2014 dari http://www.dsm5.org/Documents/Autism\%20 Spectrum\%20Disorder\%20Fact\%20Sheet.pdf.

Autism Advisory Board on Autism Spectrum Disorders. 2007. The prevalence of autism in australia: Can it be established from existing data? Diakses pada 30 April 2014 dari http://autismaus.com.au/uploads/ pdfs/ PrevalenceReport.pdf.

Autism Association of Western Australia. 2012. What is autism. Diakses pada 30 April 2014 dari http://www. autism.org.au/what-is-autism/overview.aspx. 
Burhani, R (Ed). 2012. Kemdikbud bangun 29 pusat layanan autis. Diakses pada 30 April 2014 dari http://www. antaranews.com/berita/345048/kemdikbud-bangun29-pusat-layanan-autis.

Feinstein, A. 2010. A history of autism: Conversations with the pioneers. United Kingdom: Wiley- Blackwell.

Hazliansyah. 2013. 112.000 anak Indonesia diperkirakan menyandang Autisme. Diakses pada 30 April 2014 dari http://www.republika.co.id/berita/ nasional/ umum/13/04/09/mkz2un-112000-anak-indonesiadiperkirakan-menyandang-Autisme.

Irham, M. 2014. Sekolah inklusi berlaku diskriminatif pada penyandang autis. Diakses pada 30 April 2014 dari http://www.portalkbr.com/berita/nasional/ 3193533_4202.html.

Johnson, C.A. \& Johnson, F.P. 2001. Joining Together: Group Theory and Group Skills. Boston: Allyn \& Bacon Inc.
Kirkpatrick, Donald L. 2007. Evaluating Training Programs: The four levels. San Fransisco: Berret-Koehler Publisher. Inc.

Mikail, B. 2012. Sekolah inklusi belum siap menampung $A B K$. Diakses pada 30 April 2014 dari http://health. kompas.com/read/2012/04/15/10551282/ Sekolah. Inklusi.Belum.Siap.Menampung.ABK.

Mondy, R. Wayne. 2008. Manajemen Sumber Daya Manusia. Terjemahan. Edisi ke-sepuluh jilid I. Jakarta: Erlangga.

National Research Council (2001). Educating Children with Autism. Committee on Educational Interventions for Children with Autism. Catherine Lord and James P. McGee, eds. Division of Behavioral and Social Sciences and Education. Washington, DC: National Academy Press. 